\title{
USAID: Investing in Primary Education for the Sustainable Development of Pakistan
}

\author{
Sajida Zia ${ }^{1 *}$, Sobia Siddique ${ }^{1}$, Saddam Hussain ${ }^{1}$, Tehzeeb Bano ${ }^{1}$, Mehak Shahzad ${ }^{1}$
}

${ }^{1}$ National University of Sciences and Technology, NUST, Islamabad, PAKISTAN
${ }^{*}$ Corresponding Author: sajidazia@live.com

Citation: Zia, S., Siddique, S., Hussain, S., Bano, T. and Shahzad, M. (2021). USAID: Investing in Primary Education for the Sustainable Development of Pakistan. European Journal of Sustainable Development Research, 5(4), em0169. https://doi.org/10.21601/ejosdr/11194

ARTICLE INFO

Received: 11 Jul. 2020

Accepted: 25 Jun. 2021

\begin{abstract}
Human and educational development is a prerequisite for the socio-economic development of a country. Pakistan is struggling hard to enhance quality and access of primary education to children of all the regions. USAID's partnership with local organizations and government has made gigantic efforts to raise level of equitable access to education particularly in less developed regions of the country through engagement in certain bilateral operations by providing assistance. Pakistan has multiple constraints in its educational sector; low budget, weak governance, corruption and insecurity. Since, it cannot overcome these obstacles without foreign assistance. This paper highlights the role and interventions of USAID in Pakistan for the improvement of primary education through secondary research methodology. Findings of the results shows that USAID has played a positive role in promoting the primary educational sector through improved curriculum, schools construction, teachers training and reduction in community specific barriers. Thus, it is concluded that USAID through its initiatives has driven towards fulfilling the gap in an efficient manner.
\end{abstract}

Keywords: USAID, primary education, development, empowerment, assistance, Pakistan

\section{INTRODUCTION}

Education is a driver towards development. Education matters because it is one the fundamental and most vital component that develops the young generation socially, morally as well as intellectually (Vare Paul and Scott, 2007). Investment in education is a pre-requisite for achieving sustainable development and no country can achieve sustainable development without extensive investment in human capital through educational development (Harvey and Lee, 2000). Both human development and educational development are essential for the socio-economic development of a country (Alam and Mahabubul, 2009).

Developing countries are struggling hard to achieve sustainable development through education (Kates et al., 2005). But multiple issues restrict them from achieving higher levels of education. Among these, low income and poverty are the major barriers in most of the countries (Bray and Mark, 2003). Primary education is considered to be most important for children as it develops the social, mental and cultural skills to their best capability (Birdsall et al., 2005). But the spending on primary education in developing countries is low, dropout rates are high and large number of children does not even complete their primary school (Rajkumar, Sunil and Swaroop, 2008).
Keeping in view the emergent needs of developing countries; Millennium development Goals were initiated in the year 2000 for ensuring universal primary education for all. Further, mutually formulized Sustainable Development Goals that replaced the MDGs explicitly include the quality perspective which aim for the inclusive and equitable quality education (McGregor et al., 2007). For achieving quality education particularly in primary education, universal aid and loan play an important role in countries that are unable to achieve sustainable development and need foreign assistance (Alesina et al., 2000). Developed countries are helping the poor and underdeveloped states by giving foreign aid and grants in order to give impetus for sustainable development in the recipient countries and to achieve sustainable goals (Kumi et al., 2017).

Pakistan like other developing countries, is struggling hard to achieve high levels of education particularly at the primary level in order to move towards sustainable development but the total spending on education remains extremely low (Kazmi, Wadiat and Quran, 2005). To achieve high levels of education, many organizations are giving educational aid to Pakistan. United States agency for international development USAID (an international organization) has given millions of dollars to Pakistan for educational development (Ayaz, Afsheen and Saleem, 2010). 
Being a low-income developing country and given the high depressing level of poverty rate along with the repayment of high debts makes it unfeasible for Pakistan's government to comply with the stated commitments of free education (Aslam and Monezza, 2009). Educational sector shows a decisive part in the growth and development of a country but in case of Pakistan, the fundamental educational sector has been severely neglected which can be reflected by the governments total spending on the development of educational sector (Aly and Hassan, 2007).

Pakistan is almost 50 years behind its targets of achieving primary education. Currently, with a literacy rate of $64 \%$ and expected years of schooling at 7.8 years, Pakistan is lagging in the race in educational sector development from other South Asian countries (Nepal, India, Bhutan, Srilanka and India) (Cheema, 2018). Pakistan allocates only 2 percent of its total GDP to education which is relatively the lowest in the entire South Asian region. This poor spending on education led to low literacy rate which is $53 \%$ when compared to the neighboring countries as it is lowest in the region (Leithwood et al., 2007). It is not just the limited allocation or scarce funding that acts as a source of obstruction in achieving quality education but the problem in education sector is further aggrandized by the unequal distribution of funding at different levels. For example, most of the total allocated funding for education is consumed by the higher education while limited share is available for the primary and secondary education where dire need of funding exists. So, the core primary education enhancement budget is being engulfed by other areas of education while actual purpose for which funds are allocated are left behind (Mamoon and Dawood, 2018).

During the financial year of 2015, a total of 67.76 billion federal budget was apportioned to higher education, while only 14.443 billion was assigned to primary and secondary education (Awan, Ghafoor and Zia, 2015). Some significant issues like misallocation of resources, heavy administrative cost, lack of monitoring and transparency lack as well as lack of interest of the legislative bodies in budget making process are linked with the poor performance in education sector (Kadzamira, Esme and Rose, 2003). Pakistan's involvement in the battle against extremism has also severely afflicted the progress of literacy campaign. A number of schools were blown up by the militants in KPK, Baluchistan and FATA (Davies and Layn, 2008). During the last few years, a total of 758 schools have been damaged by terrorist attacks in the KPK province. Among these, 476 were partially blown up while 164 were completely bulldozed to the ground. In addition to the terrorist attacks, natural calamities such earth quack and floods have further led to an increase in the number of destroyed schools. A total of 1694 schools were damaged by floods in the last few years (Hussain, Rana and Ali, 2012). These terrorist activities may not have made significant contribution to the poor performance of primary education, but they have led to an increase in the already worsened condition (Bushra, Zaman and Amjad, 2017). The primary educational sector in the country has been persistently sabotaged by several stubborn glitches; these can be categorized as the lack of consensus among the political leaders about the fate of education, institutional inefficiencies, consistency in poor governance and structural inefficiencies in the country (Ahmad et al., 2013).

Pakistan has to drive a long way in order to ensure primary education for all. At the primary level, total boys out of school were 2 million while total girls out of school were found to be more than 3 million, pupil-teacher ratio is 1:46 which is also in a depressing situation when compared to rest of the South Asian countries (Cheema and Ali, 2017). There is a steady but a slow improvement in the literacy rate; it has increased from 25 percent in 1980 to 45 percent in 2001 but despite such improvements, overall trend of dropout rate keeps on increasing within the primary schools, with girls drop out ratio higher than boys (Ashraf, Dilshad and Farah, 2007).

Considering all these above-mentioned problems faced by primary education in Pakistan, it would be immature to think that Pakistan can alone overcome these hurdles without any foreign assistance. There is a dire need for foreign assistance in order to make sure that no single child stays out of school.

\section{Research Hypothesis}

The testable hypothesis that can be drawn from the problem statement is that through enhanced and proper utilization of USAID assistance, government of Pakistan can:

1) Overcome the deficits in funds allocated for education

2) Improve its education indicators by providing quality education to the citizens that will eventually impact the Human Development Index (HDI)

\section{Main Objective}

The paper highlights the interventions employed by the USAID projects to improve basic primary education in Pakistan. The impacts of these interventions on educational development will also be unleashed.

\section{LITERATURE REVIEW}

Improving primary education is a precondition for developing the human resource base in developing countries to meet the changing technology strains of the 21st century (Owusu and Bema, 2018). Since the end of World War II, a diverse group of organizations have formulized in high income countries to support the development in low income countries of Africa, Asia and Latin America (Dobers, Peter and Halme, 2009). These organizations and development professionals work towards playing a significant role in the creation and implementation of worldwide educational values and standards (Chabbott and Colette, 2013).

In developing countries, problem of financing education particularly financing of the primary education is acute, thus international organization and NGOs give aid to promote educational development in these developing regions (Devarajan and Swaroop, 2000). Public-private partnerships in education have acquired huge centrality in the agendas of aid agencies focusing on education. These include the Asian Development Bank, World Bank and United States Agency for International Development (Verger, 2012). 
United States Agency for International Development (USAID) Investing in Education

USAID is investing in education for sustainable development of developing countries and to mobilize the process of democratic consolidation by expanding knowledge and accommodating values among vulnerable citizens who have little or no exposure to education (Finkel and Ernst, 2005). USAID has supported 151 basic educational programs in 45 countries that directly benefitted more than 41.6 million children and youth from 2011-2015 (USAID, 2016). The primary focus of USAID is to build the local schools and enhance capacity of teachers for improvement of quality education (Moreland and Talbird, 2006).

\section{Educational Development in Pakistan: USAID Educational Assistance}

Pakistan being a developing country faces multiple constraints in reaching the level of development where literacy rate increases and sustainable growth level is achieved (Butz and David, 2015). Quality and access of primary education for both rural and urban population is a major aspect which plays a dominant role in the development as it upholds a productive and conversant community and brings equal opportunities for all (Gylfason and Thoraldur, 2001). Literacy rate of Pakistan is $57.9 \%$, (people of age 15 or over 15 , who can read or write) among which $67 \%$ are male and $47 \%$ are females. Amid this percentage, only $10 \%$ of the children complete 12 years of schooling in Pakistan (Curtis and Lisa, 2007). While analysing the primary education hurdles USAID has promoted its interventions to raise the access to quality education for all children.

USAID is assisting Pakistan in educational sector through giving aid directly to government and NGOs (Ayaz, Afsheen and Saleem, 2010). USAID is working in Pakistan for development and economic growth. One of the prime focus of USAID is primary education (Shah, 2001). USAID educational assistance programs aims to provide education to children affected by military conflicts through increasing enrolment rates in primary schools and initiating non-formal education system in marginalized areas (Alderman and Chishti, 2004). Pakistan received a total of 75.6 million dollars from USAID in 2016 for basic primary education and post-secondary education in the form of foreign assistance (Burian et al., 2017).

USAID's Education Programs in Pakistan aim to deliver high quality education for sustainable development of the country. It targets the critical areas and marginalized communities in the districts of Sindh, Baluchistan and FATA in Pakistan (Farooq et al., 2009). The programs introduced by USAID work to make institutions effective, standardize curriculum and to make curricula gender neutral with the maintenance of equity (Ayaz and Saleem, 2010).

USAID focuses on policy interventions such as, teachers training, building new schools and repairing the already existing schools damaged by natural disasters such as floods, earthquakes and terrorist activities through providing scholarships to young talented and deserving students to pursue higher education without any obstacles Furthermore, it remains engaged for empowering local community through capacity building programs to make them self-sufficient to initiate and run programs according to their needs (Novelli, Mario and Cardozo, 2008).

\section{USAID Role in Engaging and Empowering Civil Societies}

Engagement of civil society and local community is the essential part of any development program and many institutional problems can be addressed by community involvement as it increases accountability (Mundy and Karen, 2008). In case of education, civil society can encourage the parents to send their children to schools and the community can help in the identification of critical issues (Birdsall et al., 2005). USAID provides small grants to civil society organizations for supporting the innovate activities which can reduce constraints in access of education and promote quality services of education along with building the capacity of local community to empower children through education (Naviwala, 2010).

USAID works to expand the school places in remote areas of Sindh, FATA and Baluchistan to reach the vulnerable communities especially girls (King and Hill, 2001). There is a big gap between boys' and girls' enrolment rate; USAID emphasizes on basic education reforms to improve the access of education for girls and to increase the proportion of education budget specifically for primary schools of Pakistan (Tembon and Fort, 2008).

\section{Aid Effectiveness in Developing Countries}

International organization and agencies like USAID, UNESCO and SDC have incorporated multiple education development programs in developing countries for sustainable development (Buchert, 2003). UNESCO has also under taken education development programs in Africa to improve teacher's education and collaborated with Sweden which is a donor country to Africa. By 1969, it aided officials to design Special Fund Projects in 22 expanded teacher colleges (Parker, 2000).

Impact of foreign aid on human development indicators like education has shown positive results in the form of Universal Primary Education (UPE) in Uganda (Ekaju, 2011). UPE schools of Uganda perceived a big project success with good management and engagement of donors and stakeholders; it was well received by politicians, aid agencies as a pro-poor effective policy (Nishimura et al., 2008).

Contrary to this, in Sub-Saharan Africa, issues of poor governance, weak institutions and absence of strong rule of law reduced the effectiveness of aid in the education sector (Brautigam and Knack, 2004).

Salvador formulated a Plan 2021 policy in which the top agenda was educational reforms where it involved many international actors (Edwards et al., 2015). Inter-American Development Bank (IADB), USAID, and the World Bank injected over US\$552 million in support and loans to the education zone alone (Edwards, 2012). USAID conducted roundtable strategic activities which involved educationist and representatives from NGOs, universities and other organizations (Schiefelbein, 2005). The international intervention in Plan 2021 is observed to play a decisive role as the policies were completely influenced by foreign structure 
Table 1. Aid to Pakistan through different organizations

\begin{tabular}{cccccc}
\hline Agency & Coverage & Year & Amount US (\$) & Modality & Types of Organization \\
\hline Asian development bank & National & $2002-11$ & 815,853 & Loan & Multilateral \\
\hline The world bank & Sindh, Punjab, KPK & $2005-09$ & 325.00 & Loan & Multilateral \\
\hline USAID & Sindh, Baluchistan & $2002-06$ & 213.971 & Grant & Bilateral \\
\hline CIDA & National & $2005-11$ & 130 & Grant & Bilateral \\
\hline World Food program & All provinces & $2004-2008$ & 52.00 & Grant & Multilateral \\
\hline Islamic Development Bank & National and Karachi & $2002-06$ & 35.240 & Loan & Multilateral \\
\hline
\end{tabular}

and elements and the national actors were completely relying on international agencies (Edwards, 2012).

Malawi's educational system has been severely affected by elitism; its operating structure served the needs of a small population only. Major challenge was the education of girls (Kadzamira, Esme and Rose, 2003). USAID funded the educational projects in Malawi for thirteen years (1991-2004). Four major projects include Quality Education through Support to Teaching (QUEST), Improving Education Quality (IEQ), Girls Attainment in Basic Education and Literacy (GABLE) and the Malawi Education Support Activity (MESA) (Anzar et al., 2004). USAID followed an integrated approach, it improved the quality of education from scratch, the quantity of the students enrolled in school increased through social mobilization campaigns and focused on capacity building which ultimately reduced the elitist dominance from the education sector (Chapman, Williams and Quijada, 2009). Objectives of USAID were strategic, it expanded the access to basic schooling and ensured equity by focusing on community participation and dialogues with NGOS and school management (Kleemeier and Elizabeth, 2000).

Foreign aid for primary education in Pakistan. According to some development analysts, the shift of aid or budget support to donors for the purpose of development has shifted from larger scale development towards sectoral programs due to which the assessment of aid direct impacts on educational outcomes have turned critical (Bray and Mark, 2003). In Pakistan, the poor performance of education fails to provide substantiation of aid's effectiveness (Malik and Rabea, 2007). Pakistan ranks seventh in the list of countries receiving the highest amount of aid from 2003-04 for the purpose of education. US $\$ 150.4$ million was received by Pakistan during this tenure (UNESCO, 2007).

Table 1 shows some of the largest donor's participation in the educational sector of Pakistan.

Many national and international organizations adopted government schools. Idara-e-Taleem-o-Aagahi (ITA) looks after this program in five districts with an immediate focus on the improvement of educational content. A Lahore based NGO named CARE adopted over 350 schools (Shah et al., 2005). Some International donor agencies were also engaged in this program. USAID backed the Pakistan Centre for Philanthropy (PCP) to administer a program, under which several government schools were adopted. In this program, USAID involved local NGOs and financed PCP and NGOs for its provision (Bano, 2008).

\section{Theoretical Background}

\section{Big push theory}

Big Push Theory was founded by Paul Rosenstein-Rodan in 1943. Further additions were made by Murphy, Shleifer and Robert W. Vishny in 1989 (Sachs and Warner, 1999). Basic idea of this theory is that a comprehensive investment package or a big push is helpful for bringing a sustainable development. In other words, certain amount of resources is required for developmental programs to get successful (Easterly, 2006). Scott Stern contribution on big push suggested investing in education, to produced better educated individuals as healthy and educated individuals make profitable economic choices (Henning, 2016). Since, Pakistan and United States partnered to provide access of basic primary education and quality higher education so foreign aid is among the few most discussed topics in case of development (Botes and Van, 2000).

Low-income equilibrium traps have a significant contribution in the economic development of a country therefore poor economies need some expansion to increase the size of their market and big push is essential in such cases for the purpose of development (Murphy et al., 1989). Big push refers to anything that stimulates demand. It can be a large public spending on human development or spending on infrastructure projects or program (Sachs and Warner, 1999). Big push was presented as the solution to the underdeveloped countries to develop its different sectors to compete the world (Krause, 2013). Foreign Aid is an important determinant of development in the developing world and especially in countries like Pakistan, where development needs cannot be financed by the government due to limited domestic resources (Anwar et al., 2018).

Pakistan is caught in educational poverty trap so its people are not only be able to climb out of poverty on their own therefore a Big Push is required in the form of increased aid and investment to lead them towards the takeoff condition in per capita income (Easterly, 2006). Big Push involves an increase in foreign aid along with an enhanced investment in sectors like education, health and infrastructure development (Kanbur and Sandler, 1999). Foreign aid allows poor countries to fulfill the needs of their people and have rapid acceleration of growth on their own leading to self-sustainability (Kraay and McKenzie, 2014). Pakistan is still struggling to enroll children in schools, increase literacy rate through empowerment and improve overall quality of education in the country therefore getting assistance from US based agency USAID to achieve sustainable educational development (Bruns and Rakotomalala, 2003).

Big push theory is relevant to this study as its emphasis and considerations are the fulfillment of primary needs of 
education through assistance from other countries. As access to primary education in Pakistan still continues to be a big issue which is basically the source of social profitability all over the world. In order to tackle this issue, Pakistan needs a big push and since primary education continues to be a priority here so natural resources of this country can also act as significant catalysts for the purpose of development. USAID's education programs provide education to children affected by military conflicts along with enrolling new students in schools and repairing, constructing schools and teachers training. USAID is helpful as it provides governments with a supply to make investments in multiple sectors like education, health and economic infrastructure that are required to break the cycle of deprivation. Enhancing access to educational opportunities for out of school children is the key priority for the US Government.

Due to the lack of resources, Pakistan does not pay necessary attention to education. Education is necessary for the economic growth and political stability of Pakistan. Pakistan has reduced the portion of budget for education as it relies on foreign aid for the development of its educational institutions. Once the required development has been made, the need of aid money and its percentage in GDP would decrease as private investment increases which makes a country self-reliant and paves way towards sustainable development. Foreign aid provided to the educational sector of Pakistan suggests that in the long run, total aid distribution has a significant positive relationship with the literacy rate of the country.

Aid donors have clear developmental objectives and aid plays a vital role in achievement of those objectives. Under the situation of aid dependence, aid is necessary to achieve the development objectives of a country. USAID's primary focus is to develop a stable and tolerant Pakistan with a vibrant economy by focusing on education and health. Aid has contributed to positive educational achievements over the past decades. To ensure proper utilization of big push/aid on education, USAID and Pakistan's government are assessing the success and failure of the educational programs introduced by USAID every year.

\section{Global governance theory}

Global governance originated from the study of international organizations in the words of Robert Keohane (Ozgercin, Kevin and Weiss, 2008). Globalization is an important factor that led to the emergence of Global Governance theory (Enders, 2004). Global Governance is basically a movement which spreads collaboration between multinational actors to solve development issues of mutual interest through assistance. Here, NGOs are expected to cooperate both nationally and internationally to find solutions for various social issues like education (Hewson and Sinclair, 1999). Governance of social organization refers to the systems of authoritative rules, customs and practices through which an individual manages the common concerns from local to global level (Ruggie, 2014). Global governance works to bring about reliable and logical responses in social issues that cannot be addressed by the states individually and go beyond their capacity (Ozgercin, Kevin and Weiss, 2008).
Global governance theory emerged as an example to the role of the government on research and civil society (Teegen et al., 2004). Productive labor force is the result of a good quality, efficient and justifiable educational system which is basically the source that drives towards sustainable development (Patrinos, 2014). USAID's educational programs in Pakistan provide knowledge, trainings, infrastructure and technical assistance to deliver high quality education throughout the country in accordance with the Global Governance Theory (Curtis and Lisa, 2007). Effective governance is an important rule through which order and efficiency along with public participation and accountability in the educational sector is achieved. Civil society activism brings about significant changes in reducing the major democratic deficits (Scholte, 2002). Sustainable development goal of achieving universal primary education has significantly led to an increase in primary school enrollment through an increase in per capita income for education which is the result of assistance provided by external organizations like USAID (Dreher et al., 2008).

Integration of non-governmental organizations (NGOs) into international relations would move the country towards the concept of global governance theory. It expands the traditional international relations model by giving importance to NGOs along with the state, international organizations and MNCs. All the shared prosperity challenges that we are facing require new innovative ways of working together along with wider models of collaboration. In the current scenario, a stronger basic education and skill-based training is required in Pakistan to meet the evolving needs in businesses and this obviously demands monetary support. Since, Pakistan has invested a very little amount in the educational sector that supports the global governance concept so USAID's intervention through aid has led to drastic increase in an improved enrollment rate through collaboration with international actors. USAID has played an essential part in the educational development sector of Pakistan. Common challenges like improved educational policies are in the process of being addressed to achieve the goal of increased productivity which in turn would improve the global governance. This can be done by the establishment of new schools, modernization of curriculum and improved teacher salaries.

Since Pakistan's future requires both growth and shared prosperity through external assistance in education so a solution oriented and collaborative dialogue needs to be adopted as per Global Governance Theory. Side by side, actions are needed to accelerate this work practically through encouraged leadership. There are multiple relationships between universal education and good governance. Three elements of good governance include control on corruption, accountability and political instability. International leaders agree on the point that the reestablishment of shared resources like education, workforce skills, training, infrastructure and entrepreneurial support can lead Pakistan towards an increased growth. Some sectors like education need immediate reforms by mobilizing people and resources of communities.

Enhancement in education can be achieved through USAID's investment in the educational sector of Pakistan. 
Table 2. An Overview of USAID funded Pakistan reading projects

\begin{tabular}{ccccc}
\hline \multirow{2}{*}{ Province/ Regions } & $\begin{array}{c}\text { Number of schools } \\
\text { restored/assisted }\end{array}$ & $\begin{array}{c}\text { Number of teachers trained by } \\
\text { USAID }\end{array}$ & \multicolumn{2}{c}{ Number of students enrolled } \\
\cline { 2 - 5 } & 2611 & 5758 & Girls & Boys \\
\hline Khyber Pakhtun Khwa & 1936 & 3192 & 120492 & 92778 \\
\hline Sindh & 468 & 737 & 37030 & 70098 \\
\hline Gilgit Baltistan & 1477 & 2458 & 7933 & 16545 \\
\hline AJK & 1442 & 2330 & 29507 & 37015 \\
\hline Baluchistan & & & &
\end{tabular}

Source: (GoP, 2006)

Factors like education, skill building and social security system make considerable changes in leadership, justice, productivity and unity. Education is a lifetime learning process and it is necessary for the achievement of a self-sustainable society. Therefore, global governance plays a vital role in establishment of a sustainable environment through improved educational facilities since education is essential for capacity building of the citizens for coping with sudden unpredictable problems. Also, it addresses the development issues through external assistance from organizations like USAID.

\section{RESEARCH METHODOLOGY}

Research methodology adopted for the purpose of research is qualitative in nature. Secondary data was collected through reviewing literature from multiple research articles, papers as well as case studies along with a detailed overview of both national and international reports. Data was collected regarding the interventions of USAID all over Pakistan. Various case studies have also been consulted in order to extract explicit information for the topic. For secondary data collection, two types of tools were used to instrumentalize the data. These include the interior and exterior sources of data. The internal source of data consisted of publications by the United Nation Agency for International Development (USAID), while the external data was collected from government agencies and institutions along with the work of well- reputed authors. Qualitative research method is among the most famous methods used in social sciences (Morse, 2003).

\section{Data Analysis}

The research analysis was done by collecting, synthesizing and summarizing the secondary information to get answers of the research questions; secondary information consists of data and information collected by others and archived in some form. It is useful in social sciences to get new answers from the old literature (Silverman, 2016). Content analysis technique (CAT) has been used in this study to analyze the data obtained from reports and articles. Content analysis technique is a research method which is practiced to make replicable and usable interpretations by understanding and coding recorded material (Hsieh and Shannon, 2005).

\section{RESULTS \& DISCUSSION}

USAID has rendered multiple efforts in raising the equitable access of education to Pakistan. In this regard, it has engaged in certain bilateral corporations to provide assistance in educational sector and initiated policy reforms that are in line to sustainability of Pakistan's education system (Zaidi, 2011). USAID designed and implemented programs for primary, elementary and tertiary levels but its prime focus is on basic primary education. For this, it has provided assistance in countless educational projects that are according to the requirement of areas and resulted in improved conditions of education sector (Curtis and Lisa, 2007).

USAID has provided 516 million US dollar (\$) of aid from the period of 1997-2012 which has assisted in building schools, improving infrastructure, teachers training and capacity building (Malik, 2007). Overall, it has restored 1400 schools since 2009 and trained 35900 teachers. Through its platform, the primary level learners reached to $1,349,000$. It has provided unwavering services to underserved children by building schools and successfully rehabilitated 220 schools in Federally Administered Tribal Areas (FATA) and Khyber Pakhtunkhwa including a women's college in Orakzai where 26000 students are facilitated through its initiatives (Mirhamadi et al., 2016). Likewise in Mali, USAID has constructed new schools, funded community schools, rehabilitated and restored a large number of schools along with providing quality education (MillerGrandvaux, Yolande and Yoder, 2002).

Under Sindh Basic Education Program, USAID has built 106 schools with improved infrastructure and basic facilities. 18000 scholarships were provided to students for tertiary education in Pakistan (Munshi et al, 2015). USAID has provided 17 grants worth $\$ 3$ million to reduce the community specific barriers to education for adolescent girls. Through its implementation strategies, it has committed to $\$ 70$ million, empowered and educated 200,000 adolescent girls by working in cooperation with government (Naviwala, 2016). Similarly, in Burkina Faso, girl's enrollment in primary education has increased due to USAID assisted girls friendly primary schools. It has increased to 5 times more than boys (Kazianga et al., 2013).

Pakistan reading program started in the year 2014 with USD160 million. This program has assisted 1,442 schools all over Pakistan. This project has enhanced the reading skills of children by providing reading material to schools (GoP, 2016).

\section{USAID's Primary Education Development Programs in Pakistan}

USAID has trained 177 Taleemi Islahi Jirga (TIJ)/Parent Teachers Council (PTC) in FATA to figure out educational needs, applicable solutions and capacity building with various other initiatives to meet the educational development (Khan et al., 2018, 113-136). This project (TIJ) has profound impact in improved access, quality learning and suitable environment for the education and empowerment of locals through capacity building (Mirhamadi et al., 2016). USAID further conducted 
Table 3. An Overview of USAID programs their outcomes

\begin{tabular}{|c|c|c|c|c|}
\hline Provinces/Regions & Year & Amount funded (\$) & Program name & outcome \\
\hline \multicolumn{5}{|l|}{ Punjab } \\
\hline $\begin{array}{l}\text { Khyber Pakhtoon } \\
\text { Khwa }\end{array}$ & $2013-2015$ & 300million\$ & $\begin{array}{l}\text { USAID improving education } \\
\text { quality initiative in Pakistan }\end{array}$ & $\begin{array}{c}3000 \text { young students were enrolled in technical } \\
\text { institution in nine districts } \\
\text { Strengthened local school capabilities }\end{array}$ \\
\hline Sindh & 2011-2016 & 155 million $\$$ & $\begin{array}{c}\text { Sindh Basic Education } \\
\text { Programme }\end{array}$ & $\begin{array}{c}106 \text { schools constructed } \\
\text { Increased enrolment of children }\end{array}$ \\
\hline Baluchistan & $2002-2008$ & 2billion\$ & ED-Links & $\begin{array}{c}\text { Trained 10,000 teachers } \\
\text { Quality Education to 83,000 students }\end{array}$ \\
\hline Gilgit Baltistan & $2013-2017$ & $\begin{array}{l}\text { Faculty of Education } \\
\text { Building }\end{array}$ & 1.5 million $\$$ & $\begin{array}{l}\text { Trained 6,500 students } \\
500 \text { faculty training } \\
\text { Enhanced reading of } 29,000 \text { children in } 470 \text { schools } \\
\text { Provided scholarships to } 52 \text { talented and financially } \\
\text { deserving students }\end{array}$ \\
\hline AJK & $2006-2010$ & & & $\begin{array}{l}65 \text { learning resource centres were established, } 10,000 \\
\text { primary and middle teachers were trained } \\
2300 \text { SMCs were formed to raise awareness, solved } \\
\text { educational management issues }\end{array}$ \\
\hline
\end{tabular}

Source: (Researchers' own analysis)

workshops for 1000 teachers in different districts of Pakistan, to impart teaching methods skills and strategies which in turn have improved the quality learning of pupils. 57 government officials were trained by USAID to select, plan, manage and monitor as per their needs and demands (Khan et al., 2018).

USAID has introduced an initiative of Primary Education Development Program (PEDP) in Baluchistan. USAID was a sole donor; provided $\$ 280$ million amount as assistance for the implementation of this program (Benoliel et al., 1997). Due to PEDP program, girls' primary schools have increased by $41 \%$ since 1990. The rise in girl's enrollment rate in separate primary schools was $86.2 \%$. The total of girl's primary school enrollment in Baluchistan reached to 208,053 and the dropout rates declined to an average of $11 \%$ each year, school completion rate increased to 30\% in 1990 (GoB, 1997). Projects similar to the ones was conducted and initiated in Malawi. USAID has focused on community participation in education, focused on girl's education and funded $\$ 700$ million for a fiveyear plan in 2013 which has expanded excess to primary education (Ginsburg et al., 2014).

\section{USAID Interventions in Less Developed Areas of Pakistan}

USAID has provided assistance in programs like Releasing Confidence and Creativity (RCC) in collaboration with Agha Khan Foundation and Democratic Schools by Children Resource International to develop and support the education program in early years (Hunzai, 2007). The targets of RCC was to encourage community and parental involvement and develop technical competencies in teachers through Early Child Development (ECD) programme which was successfully met and raised enrollment rate of primary schools to $80 \%$ in different districts of rural Sindh and Baluchistan (Malik and Naveed, 2012).

In Federally Administered Tribal Areas of Pakistan (FATA), USAID initiated a bottom up participatory program named Strengthened Community Resilience (SCR) through improved access to basic educational services in temporarily dislocated person hosting and return areas of Khyber Pakhtunkhwa and FATA" (Naviwala, 2016). This project (SCR) has successfully rehabilitated 65 schools in host areas. These include 37 boy and 28 girl schools, where 58 schools were of primary level. 41 schools have been provided with furniture and basic services and this has raised the enrollment rates of children in FATA schools to $62 \%$ and out of school children rate has also declined from $21 \%$ to $16 \%$ (ASER, 2015).

\section{Community Empowerment Through Education by USAID}

USAID funded project of the Primary Education Development Program (PEDP), brought management restructuring by establishing a Directorate of Primary Education which empowered women by creating employment opportunities as educators and administrator. 13 female senior district education officers and 17 sub-district education officers along with the female staff managed and supported girls at district level by conducted trainings that benefitted 8000 individuals and upgraded their teaching skills (Oduro et al., 2007). The PEDP program has in continuation designed the capacity building of local teachers by initiating a Mobile Female Teachers Training Unit (MFTTU) in Khanzoi which has empowered the local females. This program has three-month training session; initially there were 12 candidates, who after completion initiated primary education in collaboration with USAID and UNICEF in their respective villages with an $86 \%$ enrollment rates of girls (Benoliel, 1997).

Revitalizing, Innovating and Strengthening Education (RISE) project was implemented under American Institute for Research (AIR) in Muzaffarabad, Bagh and Poonch districts of AJK and Mansehra district of KP to improve the education system (Mughal, 2010). USAID has completed projects that are worth $\$ 23$ million in the earthquake affected areas of AJK by training more than 10,000 primary, middle and high school teachers. It worked to improve the rate of teacher's attendance to ensure quality education for the students of Bagh and Mansehra (Chabot, 2009). Likewise, USAID provided humanitarian assistance to Philippines on temporary basis for educational development as its communication channels were disrupted by typhoons (Lum and Margesson, 2014).

Through the transparent monitory mechanism, attendance increased from $85 \%$ to $91 \%$ in Bagh and to $93 \%$ in Mansehra. Also, the rate of absent teachers decreased from $25 \%$ to $12 \%$ in 
Table 4. An Overview Improvement of number of Girl's school and enrollment

\begin{tabular}{crccccccc}
\hline Years & $\mathbf{1 9 9 0}$ & $\mathbf{1 9 9 1}$ & $\mathbf{1 9 9 2}$ & $\mathbf{1 9 9 3}$ & $\mathbf{1 9 9 4}$ & $\mathbf{1 9 9 5}$ & $\mathbf{1 9 9 6}$ & $\mathbf{1 9 9 7}$ \\
\hline No. of school & 03 & 31 & 46 & 907 & 1,010 & 1,220 & 1,395 & 1,719 \\
\hline No. of schools enrollment & 0,206 & 2,099 & 5,035 & 110,917 & 126,075 & 139,012 & 146,119 & 149,349 \\
\hline
\end{tabular}

Source: $(G o B, 1997)$

Mansehra and from $20 \%$ to $14 \%$ in Bagh. This ensured availability of teachers, which ultimately enhanced the learning outcomes. RISE further built capacity of education managers, professionally developed 10,000 primary, middle and high school teachers and trained 2300 school management committees and parent teacher councils in Azad Jammu and Kashmir (Chabot, 2009).

USAID has ensured participation of girls in learning process in multiple program within Pakistan. An example of such program is 'Let Girls Learn' under which $\$ 4$ million was donated. This program was successfully enrolled 10,000 girls in schools (Smith, 2016). USAID provided grants under the Education Sector Reform Assistance (ESRA) program to local NGOs. Faran Education society received US \$500,000 through ESRA program and facilitated 500 schools in Karachi and Islamabad through improved planning and management (Husnain and Ali, 2010).

Contribution of USAID in access to quality basic education in Pakistan is appreciable. Through its initiatives, improved individuals and community skills have been developed along with the organizational capacity. Also, sustenance through investment in education sector has been ensured. These efforts have created a positive ripple effect in the society leading to sustainable development.

\section{Effectiveness of USAID}

Releasing Confidence and Creativity (RCC) as well as Democratic Children Schools (CDS) programs funded by USAID focus on services, trainings and technical assistance for individualized learning and teaching along with family and community involvement, access to education and equal opportunities (Shallwani and Mohammed, 2007). USAID through these programs has provided trainings to 1199 teachers and 190 principals. Side by side, they have promoted active learning material for the children to provide quality education with achieved target of $100 \%$ which resulted in increased attendance of students to $100 \% .275$ schools covered CDS and RCC project in Islamabad, Rawalpindi, Sindh and Baluchistan (Malik and Naveed, 2012).

The Sindh Basic Education Program assisted by USAID provided $\$ 155$ to the government of Sindh. This project has sustained student enrollment rates in primary, middle and secondary schools in seven districts of Sindh and Karachi. The program successfully constructed 106 schools and improved 70,000 early grade student reading skills (Unterhalter, 2017). ESRA project by USAID provided grant of US\$ 427,350 in order to provide professional development to 100 lead teachers, 1000 primary teachers and 45 learning coordinators in Lasbela and Loralai districts of Baluchistan (Husnain and Ali, 2010). Also, the school enhancement program (SEP) by ESRA has provided classroom resources to 227 schools, playground and sports kit to 142 schools, infrastructure enhancement to 235 schools. Additionally, it provided multiple primary school teachers in Baluchistan and Sindh along with a friendly and upgraded environment for students (Inayat, 2012).

The USAID had increased primary school enrollment in Baluchistan which ultimately has a chain leading to an increase in middle schools from 8,236 to 22, 766 and high school enrollment rate from 2,797 to 7, 655 in the province. Though the focus was to increase girl's access to education, boy's schools and enrollment has also improved remarkably. The number of boy schools raised from 5, 945 to 7,726 and enrollment increased from 315, 111 to 390,328 (GoB, 1997).

Table 4 represents an increase in the number of girl's schools from 503 to 1,719 and enrollment rates to 80,206 during the year 1990 to 1997 in Baluchistan where the PEDP project of USAID was implemented.

\section{CONCLUSION}

USAID has worked to revamp the lives of individual through improvements in the education sector of Pakistan. Different programs initiated by USAID are based on the priorities set by the Government of Pakistan in cooperation with USAID as funding takes place through GOP, locals, international organizations and private sector companies. USAID has accomplished its programs in an efficient manner through the bottom-up participatory approach of development. It has played a vital role in maximizing the access of education to far flung areas. Pakistan being faced with numerous challenges has meager educational budget which is not compatible to emerging needs. USAID through its initiatives has worked to fill this gap in a proficient manner. It has constructed more than 100 schools in different provinces of Pakistan which has increased enrollment, empowered locals, built individual capacities to make them self-sufficient and maintained a benchmark of quality teaching and learning. Side by side, it has rehabilitated the school infrastructure and devised a monitoring mechanism. USAID has efficiently enrolled more than 10,000 girls in schools and provided grant of US\$ 427,350 . It has provided professional development to more than 1000 primary teachers, specifically targeting the vulnerable communities of the less developed regions of Pakistan. Thus, USAID in Pakistan is assisting the government towards achieving primary education at high levels.

Author contributions: All co-authors have involved in all stages of this study while preparing the final version. They all agree with the results and conclusions.

Funding: No external funding is received for this article.

Declaration of interest: The authors declare that they have no competing interests.

Ethics approval and consent to participate: Not applicable.

Availability of data and materials: All data generated or analyzed during this study are available for sharing when appropriate request is directed to corresponding author. 


\section{REFERENCES}

Ahmad, I., Rauf, M., Rashid, A., ur Rehman, S. and Salam, M. (2013). Analysis of the problems of primary education system in Pakistan: Critical review of literature. Academic Research International, 4(2), 324. https://doi.org/10.11591/ ijere.v3i2.1805

Alam, G. M. (2009). The role of science and technology education at network age population for sustainable development of Bangladesh through human resource advancement. Scientific Research and Essays, 4(11), 12601270 .

Alderman, H. and Chishti, S. (1991). Simultaneous determination of household and market-oriented activities of women in rural Pakistan. Research in Population Economics, 7, 245-265.

Alesina, A. and Dollar, D. (2000). Who gives foreign aid to whom and why?. Journal of Economic Growth, 5(1), 33-63. https://doi.org/10.1023/A:1009874203400

Aly, J. H. (2007). Education in Pakistan: A white paper (revised). Documentation to Debate and Finalize the National Education Policy. Islamabad: Government of Pakistan, National Education Policy Review Team.

Annual Status of Education Report: ASER Pakistan 2015 National (Urban). Available at: http://aserpakistan.org/document/as er/2015/reports/national/ASER_National_Report_2015.pdf

Anzar, U., Harpring, S., Cohen, J. and Leu, E. (2004). Retrospective Pilot Study of USAID-Funded Education Projects in Malawi. Online Submission.

Ashraf, D. and Farah, I. (2007). Education and women's empowerment: Re-examining the relationship. Education, gender and empowerment: Perspectives from South Asia, 15.

Aslam, M. (2009). The relative effectiveness of government and private schools in Pakistan: are girls worse off?. Education Economics, 17(3), 329-354. https://doi.org/ 10.1080/09645290903142635

Awan, A. G. and Zia, A. (2015). Comparative Analysis of Public and Private Educational Institutions: A case study of District Vehari-Pakistan. Journal of Education and Practice, 6(16), 122-130.

Ayaz, A. and Saleem, S. (2010). Neonatal mortality and prevalence of practices for newborn care in a squatter settlement of Karachi, Pakistan: A cross-sectional study. PLoS One, 5(11), e13783. https://doi.org/10.1371/ journal.pone.0013783

Bano, M. (2006). Self-interest, rationality and cooperative behaviour: Aid and problems of cooperation within voluntary groups in Pakistan (Doctoral dissertation, University of Oxford).

Bano, M. (2008). Public Private Partnerships (PPPs) as 'anchor'of educational reforms: lessons from Pakistan. Background paper prepared for the Education for All Global Monitoring Report 2009.

Benoliel, S., O’Gara, C. and Miske, S. J. (1997). Focus on Girls: USAID Programs and Policies in Education. Center for Information and Evaluation, USAID. Washington, DC.
Birchler, K. and Michaelowa, K. (2016). Making aid work for education in developing countries: An analysis of aid effectiveness for primary education coverage and quality. International Journal of Educational Development, 48, 37-52. https://doi.org/10.1016/j.ijedudev.2015.11.008

Birdsall, N., Levine, R. and Ibrahim, A. (2005). Towards universal primary education: investments, incentives, and institutions. European Journal of Education, 40(3), 337-349. https://doi.org/10.1111/j.1465-3435.2005.00230.x

Brautigam, D. A. and Knack, S. (2004). Foreign aid, institutions, and governance in sub-Saharan Africa. Economic Development and Cultural Change, 52(2), 255-285. https://doi.org/10.1086/380592

Bray, M. (2003). Community initiatives in education: Goals, dimensions and linkages with governments. Compare: A Journal of Comparative and International Education, 33(1), 31-45. https://doi.org/10.1080/03057920302598

Buchert, L. (1995). The concept of Education for All: what has happened after Jomtien?. International Review of Education / Internationale Zeitschrift für Erziehungswissenschaft / Revue Internationale de l'Education, 41(6), 537-549. https://doi.org/10.1007/BF01263146

Burian, S. J., Ward, M., Banuri, T., Chaudhry, M. A., et al. (2017). Higher education capacity building in water resources engineering and management to support achieving the sustainable development goal for water in Pakistan. American Society for Engineering Education. https://doi.org/10.18260/1-2--28437

Bushra, Z. and Amjad, A. (2017). Women, children, and terrorism: social, economic and political costs (empirical investigation from Pakistan 2002-2015). Rom J Econ, 44, 107-120.

Butz, D. (2015). Education for development in northern Pakistan. Opportunities and constraints for rural households.

Chabbott, C. (2003). Constructing education for development: International organizations and education for all. Psychology Press.

Change, G. A. C. O. G. (2013). World in transition 4: Fighting poverty through environmental policy. Routledge.

Chapman, D. W. and Quijada, J. J. (2009). An analysis of USAID assistance to basic education in the developing world, 1990-2005. International Journal of Educational Development, 29(3), 268-280. https://doi.org/10.1016/ j.ijedudev.2008.08.005

Cheema, A. R. (2017). Education: What's holding back rural Pakistan from achieving education for all? Dawn, Sunday Magazine. Available at: https://www.dawn.com/news/ 1308070 (Accessed: 11 July 2020).

Curtis, L. A. (2007). US aid to Pakistan: Countering extremism through education reform. Washington DC: Heritage Foundation.

Davies, L. (2008). Education against extremism. Stoke on Trent, UK: Trentham Books.

Devarajan, S. and Swaroop, V. (1999). The implications of foreign aid fungibility for development assistance. The World Bank: Structure and Policies, 196-209. https://doi.org/10.1017/CBO9780511560002.008 
Dobers, P. and Halme, M. (2009). Corporate social responsibility and developing countries. Corporate Social Responsibility and Environmental Management, 16(5), 237249. https://doi.org/10.1002/csr.212

Dreher, A., Gaston, N. and Martens, P. (2008). Measuring globalisation. Gauging its Consequences. New York: Springer. https://doi.org/10.1007/978-0-387-74069-0

Dreher, A., Nunnenkamp, P. and Thiele, R. (2008). Does aid for education educate children? Evidence from panel data. The World Bank Economic Review, 22(2), 291-314. https://doi.org/10.1093/wber/lhn003

Edwards Jr, D. B. (2013). International processes of education policy formation: An analytic framework and the case of Plan 2021 in El Salvador. Comparative Education Review, 57(1), 22-53. https://doi.org/10.1086/668481

Edwards Jr, D. B., Libreros, J. A. V. and Martin, P. (2015). The geometry of policy implementation: Lessons from the political economy of three education reforms in El Salvador during 1990-2005. International Journal of Educational Development, 44, 28-41. https://doi.org/10.1016/ j.ijedudev.2015.05.001

Ekaju, J. (2011). An investigation into the relationship between the 1997 Universal Primary Education (UPE) policy and regional poverty and educational inequalities in Uganda (1997-2007) (Doctoral dissertation, University of Glasgow). https://doi.org/10.1080/03057925.2012.632842

Enders, J. (2004). Higher education, internationalisation, and the nation-state: Recent developments and challenges to governance theory. Higher education, 47(3), 361-382. https://doi.org/10.1023/B:HIGH.0000016461.98676.30

Farah, I. and Rizvi, S. (2007). Public-private partnerships: Implications for primary schooling in Pakistan. Social Policy \& Administration, 41(4), 339-354. https://doi.org/ 10.1111/j.1467-9515.2007.00557.x

Farooq, M., Hedieh, M. and Waleed, Z. (2009). Developing FATA, A white paper for USAID. A white paper prepared for United States Agency for International Development.

Finkel, S. E. and Ernst, H. R. (2005). Civic education in postapartheid South Africa: Alternative paths to the development of political knowledge and democratic values. Political Psychology, 26(3), 333-364. https://doi.org/10.1111 /j.1467-9221.2005.00421.x

Ginsburg, M., Klauss, R., Nankhuni, F., Nyirongo, L., Omowoyela, J. S., Richardson, E., ... \& Willimann, C. (2014). Engaging community members in enhancing educational quality: Studies of the implementation of the Primary School Improvement Programme in Malawi. Southern African Review of Education with Education with Production, 20(1), 30-57.

Government of Balochistan Education Department. (1997). Balochistan Education Management Information System (BEMIS) Data.

Grantham-McGregor, S., Cheung, Y. B., Cueto, S., Glewwe, P., Richter, L., Strupp, B. and International Child Development Steering Group. (2007). Developmental potential in the first 5 years for children in developing countries. The Lancet, 369(9555), 60-70. https://doi.org/10.1016/S0140-6736(07)60032-4
Gylfason, T. (2001). Natural resources, education, and economic development. European Economic Review, 45(46), 847-859. https://doi.org/10.1016/S0014-2921(01) 00127-1

Harvey, L. (2000). New realities: The relationship between higher education and employment. Tertiary Education \& Management, 6(1), 3-17. https://doi.org/10.1080/13583883. 2000.9967007

Hewson, M., Sinclair, T. J. and Sinclair, T. (Eds.). (1999). Approaches to global governance theory. Suny Press.

Hill, M. A. and King, E. (1995). Women's education and economic well-being. Feminist Economics, 1(2), 21-46. https://doi.org/10.1080/714042230

Hsieh, H. F. and Shannon, S. E. (2005). Three approaches to qualitative content analysis. Qualitative health research, 15(9), 1277-1288. https://doi.org/10.1177/104973230527 6687

Hunzai, Z. N. (2007). Early years education in Pakistan: trends, issues and strategies. International Journal of Early Years Education, 15(3), 297-309. https://doi.org/10.1080/ 09669760701516975

Hussain, R. and Ali, S. (2010). Improving public school teachers in Pakistan: Challenges and opportunities. Improving Schools, 13(1), 70-80. https://doi.org/10.1177/ 1365480209352404

Inayat, M. (2012). Towards universal primary education: a case study of US development assistance to education reform in Pakistan (Master's thesis, Universitetet i Tromsø).

Kadzamira, E. and Rose, P. (2003). Can free primary education meet the needs of the poor?: evidence from Malawi. International Journal of Educational Development, 23(5), 501-516. https://doi.org/10.1016/S0738-0593(03)00026-9

Kazmi, S. W. and Quran, H. (2005). Role of education in globalization: A case for Pakistan. SAARC Journal of Human Resource Development, 1(1), 90-107.

Kerwin, D. (2016). How robust refugee protection policies can strengthen human and national security. Journal on Migration and Human Security, 4(3), 83-140. https://doi.org/10.14240/jmhs.v4i3.64

Khan, M. A., Kanwal, N. and Wang, L. (2018). Violent attacks on education in the tribal areas of Pakistan and the role of NGOs in providing educational services. Conflict, Security \& Development, 18(2), 113-136. https://doi.org/10.1080/ 14678802.2018.1447861

King, E. M. and Hill, M. A. (1993). Women's education in developing countries: Barriers, benefits, and policies. The World Bank. https://doi.org/10.1596/0-8018-4534-3

Kleemeier, E. (2000). The impact of participation on sustainability: an analysis of the Malawi rural piped scheme program. World Development, 28(5), 929-944. https://doi.org/10.1016/S0305-750X(99)00155-2

Kumi, E., Ibrahim, M. and Yeboah, T. (2017). Aid volatility and structural economic transformation in sub-Saharan Africa.

Leithwood, K. and Mascall, B. (2009). Distributing leadership to make schools smarter: Taking the ego out of the system (pp. 241-270). Routledge. 
Lum, T. and Margesson, R. (2014). Typhoon Haiyan (Yolanda): US and international response to Philippines disaster. Current Politics and Economics of South, Southeastern, and Central Asia, 23(2), 209.

Malik, R. (2007). Aid effectiveness and the role of donor intervention in the education sector in Pakistan-a review of issues and literature.

Malik, R. and Naveed, A. (2012). Financing education in Pakistan: The impact of public expenditure and aid on educational outcomes. Research Consortium on Educational Outcomes and Poverty (RECOUP).

Mamoon, D. (2018). Progressing Pakistan should ensure quality education for all. Journal of Social and Administrative Sciences, 5(1), 9-14.

Manion, C. and Menashy, F. (2013). The prospects and challenges of reforming the World Bank's approach to gender and education: Exploring the value of the capability policy model in The Gambia. Journal of Human Development and Capabilities, 14(2), 214-240. https://doi.org/10.1080/ 19452829.2012.693909

Memon, G. R. (2007). Education in Pakistan: The key issues, problems and the new challenges. Journal of Management and Social Sciences, 3(1), 47-55.

Miller-Grandvaux, Y. and Yoder, K. (2002). A literature review of community schools in Africa.

Mirahmadi, H., Ziad, W., Farooq, M. and Lamb, R. (2016). Empowering Pakistan's civil society to counter violent extremism. Contemporary Readings in Law and Social Justice, 8(1), 188. https://doi.org/10.22381/CRLSJ8120168

Moreland, S. and Talbird, S. (2006). Achieving the millennium development goals: The contribution of fulfilling the unmet need for family planning.

Morse, J. M. (2003). Principles of mixed methods and multimethod research design. Handbook of Mixed Methods in Social and Behavioral Research, 1, 189-208.

Mundy, K. (2008). From NGOs to CSOs: Social Citizenship, Civil Society and "Education for All"--An Agenda for Further Research. Current Issues in Comparative Education, 10, 32-40.

Naviwala, N. (2010). Harnessing local capacity: US assistance and NGOs in Pakistan. John F. Kennedy School of Government.

Naviwala, N. (2016). Pakistan's education crisis: The real story. Woodrow Wilson International Center for Scholars.

Nishimura, M., Yamano, T. and Sasaoka, Y. (2008). Impacts of the universal primary education policy on educational attainment and private costs in rural Uganda. International Journal of Educational Development, 28(2), 161-175. https://doi.org/10.1016/j.ijedudev.2006.09.017

Novelli, M. and Cardozo, M. T. L. (2008). Conflict, education and the global south: New critical directions. International Journal of Educational Development, 28(4), 473-488. https://doi.org/10.1016/j.ijedudev.2008.01.004

Oduro, G., Dachi, H., Fertig, M. and Rarieya, J. (2007). Research project-leadership and management of change for quality improvement.
Owusu, M. B. (2018). Aid for basic education development in Ghana-the recipients' experience (Doctoral dissertation, University of Glasgow).

Ozgercin, K. V. and Weiss, T. G. (2009). The evolution of global governance: theory and practice. International Relations: Encyclopedia of Life Support Systems, 137-155.

Padgett, D. K. (2016). Qualitative methods in social work research (Vol. 36). Sage publications.

Parker, F. (2000). UNESCO's aid to teacher education in Africa. Peabody Journal of Education, 48(2), 167-171. https://doi.org/10.1080/01619567109537784

Pilgrim, N., Mathur, S., Gottert, A., Rutenberg, N. and Pulerwitz, J. (2016). Building evidence to guide PrEP introduction for adolescent girls and young women. https://doi.org/10.31899/hiv7.1008

Rahman, T. (2010). National Institute of Pakistan Studies October 2010.

Rajkumar, A. S. and Swaroop, V. (2008). Public spending and outcomes: Does governance matter?. Journal of Development Economics, 86(1), 96-111. https://doi.org/ 10.1016/j.jdeveco.2007.08.003

Rashid, A. (2000). Engaging with Basic Education in Pakistan. SAHE Education Watch Report. Lahore: SAHE.

Rehman Cheema, A. and Ali, S. (2017). Beyond Tayyaba: tackling rural poverty to reduce child labour. South Asia@ LSE.

Robert, K. W., Parris, T. M. and Leiserowitz, A. A. (2005). What is sustainable development? Goals, indicators, values, and practice. Environment: Science and Policy for Sustainable Development, 47(3), 8-21. https://doi.org/10.1080/ 00139157.2005 .10524444

Ruggie, J. G. (2014). Global governance and "new governance theory": Lessons from business and human rights. Global Governance: A Review of Multilateralism and International Organizations, 20(1), 5-17. https://doi.org/10.1163/ 19426720-02001002

Sajid, I. (2012). Over 3,000 schools destroyed in militancy, disasters: Official. The Express Tribune, June 15. Available at: https://tribune.com.pk/story/393911/over-3000804schools-destroyed-in-militancy-disasters-official (Accessed: 11 July 2020).

Schiefelbein, E. and Simmons, J. (2005). Determinants of school achievement: a review of the research for developing countries. Manuscript reports/IDRC; 9.

Scholte, J. A. (2002). Civil society and democracy in global governance. Global Governance: A Review of Multilateralism and International Organizations, 8(3), 281-304. https://doi.org/10.1163/19426720-00803004

Shah, G. H., Bari, F. and Ejaz, N. (2005). The role of NGOs in basic and primary education in Pakistan: NGO pulse report. Lahore University of Management Sciences.

Shah, G. H., Bari, F. and Ejaz, N. (2005). The role of NGOs in basic and primary education in Pakistan: NGO pulse report. Lahore University of Management Sciences. 
Shah, N. M., Ahmad, N. and Sathar, Z. A. (1986). Changes in Female Roles in Pakistan: Are the Volume and Pace Adequate? [with Comments]. The Pakistan Development Review, 25(3), 339-369. https://doi.org/10.30541/ v25i3pp.339-369

Stewart, D. W. and Kamins, M. A. (1993). Secondary research: Information sources and methods (Vol. 4). Sage. https://doi.org/10.4135/9781412985802

Teegen, H., Doh, J. P. and Vachani, S. (2004). The importance of nongovernmental organizations (NGOs) in global governance and value creation: An international business research agenda. Journal of international business studies, 35(6), 463-483. https://doi.org/10.1057/palgrave.jibs. 8400112

Unterhalter, E. (2017). A review of public private partnerships around girls' education in developing countries: Flicking gender equality on and off. Journal of International and Comparative Social Policy, 33(2), 181-199. https://doi.org/ 10.1080/21699763.2017.1328612
Vare, P. and Scott, W. (2007). Learning for a change: Exploring the relationship between education and sustainable development. Journal of Education for Sustainable Development, 1(2), 191-198. https://doi.org/10.1177/ 097340820700100209

Verger, A. (2012). Framing and selling global education policy: the promotion of public-private partnerships for education in low-income contexts. Journal of Education Policy, 27(1), 109-130. https://doi.org/10.1080/02680939. 2011.623242

Watson, C., Lone, T., Qazi, U., Smith, G. and Rashid, F. (2016). Shock-responsive social protection systems research.

Welch, A. R. and Zhen, Z. (2008). Higher education and global talent flows: Brain drain, overseas Chinese intellectuals, and diasporic knowledge networks. Higher Education Policy, 21(4), 519-537. https://doi.org/10.1057/hep.2008.20

Zaidi, S. A. (2011). Who benefits from US aid to Pakistan?. Economic and Political Weekly, 103-109. 